Vol. 1, No. 1; Jan - Mar (2021)
Quing: International Journal of Commerce and
Management
Available at https://quingpublications.com/journals/ijcm

\title{
Service Quality Dimensions in the Banking Sector
}

\section{Dr. S. Revathi ${ }^{\star}$}

Assistant Professor, Department of Bank Management (SS), Ethiraj College for Women, Chennai, TN, IND.

\begin{tabular}{|c|c|}
\hline ARTICLE INFO & ABSTRACT \\
\hline $\begin{array}{l}\text { Received: } 04-11-2020 \\
\text { Received in revised form: } \\
\text { 27-01-2021 } \\
\text { Accepted: } 01-02-2021 \\
\text { Available online: } \\
\text { 30-03-2021 } \\
\text { Keyw ord s: } \\
\text { Service Quality; } \\
\text { SERVQUAL; } \\
\text { Tangibility; } \\
\text { Reliability; } \\
\text { Responsiveness; } \\
\text { Assurance; } \\
\text { Empathy. }\end{array}$ & $\begin{array}{l}\text { The dynamic role played by services marketing in the growth and } \\
\text { development of any country is tremendous and inevitable, since emphasis is } \\
\text { on to delivery of quality services in all the sectors. This paper examines the } \\
\text { discriminatory power of service quality dimensions regarding 'Tangibility', } \\
\text { 'Reliability', 'Responsiveness', 'Assurance', and 'Empathy' with respect to } \\
\text { Public bank, Private Bank and Foreign Bank. The standardized } \\
\text { questionnaire is used to collect the data and SPSS package is used to carry } \\
\text { out percentage and Multiple Discriminant Analysis. }\end{array}$ \\
\hline
\end{tabular}

(C) 2021 Quing: IJCM, Published by Quing Publications. This is an open access article under the CC-BY 4.0 license, which allows use, distribution and reproduction in any medium, provided the original work is properly cited.

DOI: https://doi.org/10.54368/qijcm.1.1.0005

\subsection{INTRODUCTION}

The contribution of services marketing to Indian economic GDP is remarkable with the banking sector is being one of the major service sectors of our country. It is pertinent that banks have to give services with quality to their customers, because they have to sustain in the market and also to maintain long term relationships with the customer. Due to vigorous competition and dynamic changes in the economic policy during recent times, it is compulsory for the banking sector to provide enhanced quality services because the cost spent on acquiring new customers is five times more than that of retaining existing customers. Therefore, the study attempts to examine the dimensions of banking service quality.

\subsection{Literature Review}

Parasuraman et al., (1988) "SERVQUAL model is adopted for the present study, which comprising of five service quality dimensions which is tangibility, reliability, responsiveness,

\footnotetext{
^Corresponding author's e-mail: phd30062020@gmail.com (Dr. S. Revathi)
} 
assurance and empathy". Tangibility denotes appearance and physical facilities of the bank. Reliability denotes how an employee renders promised service to customer and also the way of handling customer's problem. Responsiveness refers to how employees render their services to customers based on the needs and wants of the customers and employees in volunteering to do service to customers. Assurance refers the way of trust worthy service to customers. Empathy refers caring and personal attention to the customers by the employee. According to Zeithmal (2000) an important area for research is service quality, subsequently it is the foundation for building satisfying and long-lasting customer relationships. Customers will do whole assessment of service quality (Eshghi et al., 2008).

\subsection{Objective of the Study}

- To examine the discriminatory power of the service quality dimensions in Public Bank, Private Bank and Foreign Bank.

\subsection{RESEARCH METHODOLOGY}

SERVQUAL model of Parasuraman et al., (1988) comprises of 20 items as adopted for the study with statement being measured by a five-point Likert's scale ranging from " $5=$ strongly agree to 1 = strongly disagree". The data was collected through primary sources from 673 Respondents of Public Bank, Private Bank and Foreign Bank in Chennai city. Cronbach's Alpha is used to measure the questionnaire reliability, the score of Cronbach's Alpha is 0.93, proved that the questionnaire is reliable. SPSS version 18 is applied for the analysis of data using percentages and multiple discriminant analysis.

\subsection{ANALYSIS AND INTERPRETATION}

\subsection{Respondents Profile based on Demographic}

The bank customers profile based on demographic reveals that male respondents were majority with " $41-50$ " years of age group and are salaried. The income of their family is ₹25,001 to $₹ 50,000$ and they have 6-10 years of work experience. The respondents belonging to public banks are $50 \%$, private banks $40 \%$ and for private bank $10 \%$.

\subsection{Dimensions of Service Quality on Types of Banks as a Discriminator}

The respondents of the different bank (Public, Private and Foreign) may have different levels of perception with respect to the service quality dimensions. Therefore, this section attempts to determine the service quality dimensions which discriminate the different types of bank respondents.

Type of banks is considered as the dependent variable and the Service Quality dimensions namely, "Tangibility", "Reliability", "Responsiveness", "Assurance”, and "Empathy" were taken as an independent variable. Among the total respondents of 673, the numbers of respondents of public banks were 337, private banks were 269 and foreign banks were 67. The perceptions of the three types of respondents on the service quality dimensions have been examined with mean scores. The One-Way Analysis of Variance is used to find out the statistically significant differences among them. Discriminate power of the service quality dimensions have been measured with Wilks' Lambda score. The smaller the Wilks' Lambda for an independent variable, the more that variable contributes to the discriminant function. Table 1, given below shows the mean value scores and equality of group means test which include Wilks' Lambda, F-value and its significance. 
Table 1 - Type of Banks - Mean Values and Equality of Group Means Test

\begin{tabular}{|l|r|r|r|r|r|l|}
\hline $\begin{array}{c}\text { Service Quality } \\
\text { Dimensions }\end{array}$ & \multicolumn{1}{c|}{$\begin{array}{c}\text { Public } \\
\text { Banks }\end{array}$} & \multicolumn{1}{c|}{$\begin{array}{c}\text { Private } \\
\text { Banks }\end{array}$} & \multicolumn{1}{c|}{$\begin{array}{c}\text { Foreign } \\
\text { Banks }\end{array}$} & \multicolumn{1}{c|}{$\begin{array}{c}\text { Wilks' } \\
\text { Lambda }\end{array}$} & \multicolumn{1}{c|}{ F } & \multicolumn{1}{c|}{ Sig. } \\
\hline Tangibility & 15.21 & 15.78 & 15.46 & 0.989 & 3.892 & $0.021^{*}$ \\
\hline Reliability & 15.00 & 15.21 & 14.37 & 0.991 & 3.208 & $0.041^{*}$ \\
\hline Responsiveness & 12.89 & 13.39 & 12.82 & 0.994 & 1.860 & $0.157^{\mathrm{NS}}$ \\
\hline Assurance & 15.33 & 15.46 & 14.64 & 0.991 & 2.904 & $0.055^{\mathrm{NS}}$ \\
\hline Empathy & 12.67 & 13.52 & 12.40 & 0.984 & 5.618 & $0.004^{* *}$ \\
\hline N Value & 337 & 269 & 67 & & & \\
\hline
\end{tabular}

From Table 1 it is inferred that there exists among customers significant difference with the public, private and foreign banks for only three dimensions of service quality, since their respective ' $F$ ' statistics were significant at five and one percent level. The discriminant power is noticed higher among Tangibility and Reliability at five percent and Empathy at one percent, since, their respective Wilks' Lambda is 0.989 and 0.991 at five percent level and 0.984 at one percent level. Wilks' Lambda for the two dimensions of service quality, Responsiveness (0.994) and Assurance (0.991) is found to be non-significant. Hence, these two dimensions of service quality do not contribute to discrimination among public, private and foreign banks.

Table 2 - Eigenvalues and Wilks' Lambda

\begin{tabular}{|c|r|r|r|r|r|r|r|c|}
\hline Function & Eigenvalue & $\begin{array}{c}\text { \% of } \\
\text { Variance }\end{array}$ & $\begin{array}{c}\text { Cumulative } \\
\text { \% }\end{array}$ & $\begin{array}{c}\text { Canonical } \\
\text { Correlation }\end{array}$ & $\begin{array}{c}\text { Wilks' } \\
\text { Lambda }\end{array}$ & $\begin{array}{c}\text { Chi- } \\
\text { square }\end{array}$ & df & Sig. \\
\hline 1 & $0.027(\mathrm{a})$ & 59.2 & 59.2 & 0.162 & 0.956 & 29.937 & 10 & 0.001 \\
\hline 2 & $0.018(\mathrm{a})$ & 40.8 & 100.0 & 0.135 & 0.982 & 12.231 & 4 & 0.016 \\
\hline
\end{tabular}

Canonical Correlation of 0.162 indicates $59.2 \%$ of the variance is explained by function 1

Canonical Correlation of 0.135 indicates $40.8 \%$ of the variance explained is by function 2

Table 2 shows that out of the three discriminant functions, the first two functions are statistically significant at $1 \%$ and $5 \%$ level. Wilks' Lambda for function 1 is 0.956 with Chi-square is 29.937; $\mathrm{df}=10$ and $\mathrm{p}$-value $=0.001$. Test of function 2 shows Wilks' Lambda is 0.982 with chi-square 12.231; $\mathrm{df}=4$ and $\mathrm{p}$-value $=0.016$. Thus, the functions together, discriminate significantly the types of banks. Since the chi-square statistics corresponding to Wilks' Lambda is significant for the first two functions, it reveals that there exists relationship between the dependent groups and the independent variables.

Further, the effectiveness of the discriminate function is explained through Eigen values. Table 2 shows Eigen value of 0.027 for function 1 and 0.018 for function 2 . It shows that the first discriminant function is the most effective for groups differentiating. The next discriminant function is the next most helpful function.

The multiple correlations between the predictors and the discriminant function are referred to as the canonical correlation. From Table 2, a canonical correlation of 0.162 and 0.135 for function 1 and function 2 respectively suggests function 1 explains 59.2 percent of variance in the types of banks and function 2 explains 40.8 percent of the variance. 
Table 3 - Standardised Canonical Discriminant Function Coefficients

\begin{tabular}{|l|r|r|}
\hline \multirow{2}{*}{$\begin{array}{c}\text { Dimensions of Service } \\
\text { Quality }\end{array}$} & \multicolumn{2}{|c|}{ Function } \\
\cline { 2 - 3 } & $\mathbf{1}$ & \multicolumn{1}{c|}{$\mathbf{2}$} \\
\hline Tangibility & 0.939 & -0.572 \\
\hline Reliability & -0.295 & 0.732 \\
\hline Responsiveness & -0.115 & -0.228 \\
\hline Assurance & -0.479 & 0.546 \\
\hline Empathy & 0.800 & 0.472 \\
\hline
\end{tabular}

"Tangibility", "Reliability", "Responsiveness", "Assurance", and "Empathy" are the standardised coefficients for each dimension of banking service quality (vide Table 3). The higher value standardized coefficient denotes that the higher contribution to the respective service quality dimensions among the banks as discrimination. The validity and reliability of first function is more, so first functions have been taken for interpretation. In Function 1, Tangibility has the highest discriminating power with coefficient of 0.939 , subsequently Empathy with coefficient of 0.800 and Assurance with coefficient of 0.479 .

The discriminant loadings denote the correlation between the constructs and the discriminant function. The relationship will be stronger between the factor and the discriminant function, if discriminant loading is larger. The loadings of discriminant are presented in Table 4 which denotes the correlations between the dimensions of banking service quality and the discriminant function.

Table 4 - Structure Matrix

\begin{tabular}{|l|r|r|}
\hline \multirow{2}{*}{$\begin{array}{c}\text { Dimensions of Service } \\
\text { Quality }\end{array}$} & \multicolumn{2}{|c|}{ Function } \\
\cline { 2 - 3 } & \multicolumn{1}{|c|}{$\mathbf{1}$} & \multicolumn{1}{c|}{$\mathbf{2}$} \\
\hline Tangibility & $0.649\left(^{*}\right)$ & 0.131 \\
\hline Empathy & $0.646\left(^{*}\right)$ & 0.548 \\
\hline Responsiveness & $0.395\left(^{*}\right)$ & 0.272 \\
\hline Reliability & 0.160 & $0.693\left(^{*}\right)$ \\
\hline Assurance & 0.069 & $0.680\left(^{*}\right)$ \\
\hline
\end{tabular}

(*) The largest absolute correlation of any discrimination feature between each variable.

Table 4 inferred that, Tangibility with discriminant loading of $0.649\left(^{*}\right)$ has the highest correlation with function 1 and highly discriminates among the dimensions of service quality.

Table 5 - Classification Function Coefficients

\begin{tabular}{|l|r|r|r|}
\hline \multirow{2}{*}{$\begin{array}{c}\text { Dimensions of Service } \\
\text { Quality }\end{array}$} & \multicolumn{3}{|c|}{ Type of bank } \\
\cline { 2 - 4 } & Public Bank & Private Bank & Foreign Bank \\
\hline Tangibility & 1.043 & 1.161 & 1.231 \\
\hline Reliability & 1.296 & 1.268 & 1.138 \\
\hline Responsiveness & 0.489 & 0.475 & 0.510 \\
\hline Assurance & 1.141 & 1.086 & 1.003 \\
\hline Empathy & 0.181 & 0.267 & 0.179 \\
\hline (Constant) & -31.803 & -33.289 & -30.508 \\
\hline
\end{tabular}


From Table 5 it is inferred that the perception of respondents varies with respect to types of banks. It is found that respondents of public banks and private banks have given high importance to Reliability with values 1.296 and 1.268 respectively whereas for foreign bank, importance is given to Tangibility with value of 1.231 . The second important dimension of service quality with respect to public banks in Assurance (1.141), with respect to public banks is Tangibility (1.161) and with respect to foreign bank is Reliability with value of 1.138 .

Comparison of the classification function coefficients among the public, private and Foreign Bank respondents reveals that Reliability is high in public bank, Empathy is high in private bank and Tangibility is high in foreign bank.

Table 6 - Classification Results(a)

\begin{tabular}{|l|r|r|r|c|}
\hline Type of Bank & \multicolumn{1}{|c|}{ Public Bank } & Private Bank & Foreign Bank & \multicolumn{1}{c|}{ Total } \\
\hline Private Bank & $84(31.2 \%)$ & $112(41.6 \%)$ & $73(27.1 \%)$ & $269(100.0 \%)$ \\
\hline Public Bank & $132(39.2 \%)$ & $105(31.2 \%)$ & $100(29.7 \%)$ & $337(100.0 \%)$ \\
\hline Foreign Bank & $18(26.9 \%)$ & $15(22.4 \%)$ & $34(50.7 \%)$ & $67(100.0 \%)$ \\
\hline Total & $234(100.0 \%)$ & $232(100.0 \%)$ & $207(100.0 \%)$ & $673(100.0 \%)$ \\
\hline
\end{tabular}

(a) $41.3 \%$ of original grouped cases correctly classified.

The examination of the Classification Table 6 reveals that the discrimination amongst the three types of the banks with respect to five service quality dimensions is successful in classifying $41.3 \%$ of the original grouped respondents.

\subsection{CONCLUSION}

The results revealed that Tangibility has the highest discriminating power followed by Empathy and Assurance. Also, the discrimination among the types of banks with respect to service quality dimensions is successful in classifying $41.3 \%$ of the originally grouped respondents.

\section{REFERENCES}

El Saghier, N., \& Nathan, D., (2013, April) “Service Quality Dimensions and Customers' Satisfactions of Banks in Egypt". In Proceedings of the 20 $0^{\text {th }}$ International Business Research Conference (Vol. 13).

Eshghi, A., Roy, S., \& Ganguli, S., (2008), "Service Quality and Customer Satisfaction: An Empirical Investigation in Indian Mobile Telecommunications Services", Marketing Management Journal, 18(2), pp. 119 - 144.

Hafeez, S., \& Muhammad, B., (2012) “The Impact of Service Quality, Customer Satisfaction and Loyalty Programs on Customer's Loyalty: Evidence from Banking Sector of Pakistan", International Journal of Business and Social Science, 3(16), pp. 200-209.

Muhammad Awan, H., Shahzad Bukhari, K., \& Iqbal, A., (2011) "Service quality and customer satisfaction in the banking sector: A comparative study of conventional and Islamic banks in Pakistan". Journal of Islamic Marketing, 2(3), pp. 203-224.

Parasuraman, A., Zeithaml, V. A., \& Berry, L. L., (1988), "SERVQUAL: a multi-item scale for measuring consumer perceptions of the service quality", Journal of Retailing, 64(1), pp. 12-40. Available at Parasuraman-et-al-Journal-of-Retailing-1988-2.pdf. 
Prasad, E. H., \& Prasad, G. V., (2015) "Service Quality of Commercial Banks in Rural Areas (A Study of Selected Commercial Banks in Karimnagar District of Telangana State)". Pacific Business Review International, 7(12), pp. 81-92.

Ravichandran, K., Mani, B. T., Kumar, S. A., \& Prabhakaran, S., (2010) "Influence of service quality on customer satisfaction application of SERVQUAL model" International Journal of Business and Management, 5(4), pp. 117-124.

Revathi, S., \& Saranya, S. A., (2016) “Dimensions of Service Quality and Customer Satisfaction: Banking Sector". International Journal of Advanced Scientific Research \& Development (IJASRD), 03 (03/I), [Special Issue - Sep' 2016], pp. 55-66.

Revathi, S., \& Saranya, S. A., (2017) "Relational Bonds, Service Quality, Customer Satisfaction and Customer Loyalty (A Comparative Study among Public, Private and Foreign Banks)", Journal of Emerging Technologies and Innovative Research, 4(8), pp. 111-115. Available at http://www.jetir.org/papers/JETIR1708024.pdf.

Shanka, M. S. (2012) "Bank service quality, customer satisfaction and loyalty in Ethiopian banking sector". Journal of Business Administration and Management Sciences Research, 1(1), pp. 1-9.

Zeithaml, V., (2000) "Service quality, profitability and the economic worth of customers: What we know and what we need to learn", Journal of the Academy of Marketing Science, 28 (1), pp. 67 85. 